\title{
Nokre tankar frå ei nattevakt
}

Midt på natta. «Pip, pip!»

Du vil skrive deg ut, NO! Frivillig innlagt,

lèt deg ikkje overbevise om å bli.

Sjukehistorie: kronisk paranoid, samarbeider dårleg. Uff da...

Traskar gjennom tomme korridorar. «Klikk, klakk».

Første møte: Du står med posane pakka og klar til å reise.

Samtalen går ikkje bra. Eg når ikkje gjennom. Du stoler ikkje på meg, på oss, på sjukehuset.

Eg kjenner at dette greier eg ikkje å stå i åleine. Du vil ut. Personalet er redd for kva som skjer om du blir nekta å reise. Eg søkjer tryggleik i bakvakt. Uaktuelt at du får reise under slike omstende. Du må haldast på naudrett.

Hentar deg inn igjen for å overbringe beskjeden om at du må bli.

Røsta di blir høg, adrenalinen er tjukk i lufta.

Plutseleg kjem du mot meg!

Dunk-dunk-dunk-dunk-dunk. Hjartet mitt er i halsen.

«No slår du til meg! Rekk eg å løyse ut alarmen? Går du først på meg eller sjukepleiaren? Håpar sonen min søv trygt. Blir det vondt? Kor langt er det til døra?» Retrett baklengs ut døra, der står meir personale.

Luskar ut av avdelinga.
Emmen smak i munnen. Hjartet dunkar framleis. Eg er redd, nesten på gråten redd. Så slår det meg: Så enormt redd du er!

Dette er tankar eg gjorde meg under ei nattevakt på psykiatrisk klinikk. Opplevinga sit i meg. Kvifor det?

Det forste som slår meg, er at det er naturleg å bli redd og få fryktreaksjon med alle autonome aktiveringar når ein føler at ein er fysisk truga av nokon. Eg har aldri blitt angripe før, og eg trur dette er det næraste eg har vore. I denne situasjonen var eg fysisk klart underlegen pasienten, og eg kjende kor sårbar eg var. Men den kjensla gjekk fort over.

Det som sat igjen var ei djup kjensle av avmakt og hjelpelausheit.

Avmakt over at orda mine ikkje strakk til. Som lege og psykiater er eg vant med å kunne bruke ord for å nå inn til folk, skape dialog og forståing begge vegar. Men denne natta blei pasienten berre meir provosert og mistruisk jo meir eg prøvde å seie. Når ein ikkje har ord som kan skape bru mellom seg sjølv og pasienten, kva har ein då igjen?

Hjelpelausheiten eg kjende, trur eg var både min og pasienten sin. Pasienten prøvde fortvila å få oss til å forstå kvifor han måtte heim, men opplevde sikkert som eg at orda ikkje var til nytte. Han fekk bekrefta at han ikkje kunne stole på oss, og same kva han sa høyrde ikkje eg på han. Eg tenkjer at han prøvde å hjelpe seg sjølv så godt han kunne i den situasjonen han var i, utan at han lukkast.

Kjensla av ikkje å vite korleis eg kunne få kommunisert med pasienten, sat som ein klump i magen. Eg var hjelpelaus i høve til å finne ei opning, ein relasjonsbyggande, tillitsskapande gest overfor denne pasienten. Det var nesten som om eg hadde pasienten sitt liv i hendene mine, så intens var redsla hans og det inderlige ønsket om å reise heim.

Ingenting av det eg har lært eller erfart (så langt) gjorde nokon skilnad i denne situasjonen. Korleis legg ein frå seg noko slikt når ein hengjer av seg legefrakken og kjem heim til familien?

\section{Jeanette Bjørke-Bertheussen \\ bjje@sus.no \\ Psykiatrisk divisjon \\ Stavanger universitetssjukehus}

Jeanette Bjørke-Bertheussen (f. 1980) er lege i spesialisering ved Psykiatrisk klinikk.

Mottatt 7.2. 2011 og godkjent 17.3. 2011. Medisinsk redaktør Erlend Hem.

\section{Kommentar}

\section{Når pasienten truer eller angriper}

Det føles dypt urettferdig og frustrerende når man som helsepersonell blir sterkt kritisert, truet eller angrepet av den man ønsker å hjelpe. Særlig ille blir det dersom hendelsen etterlater seg en sterk følelse av maktesløshet og der det har vært en reell fare for legemsbeskadigelse og med frykt for å dø.

Oppslag i medier kan skape det inntrykket at personer med psykiske problemer generelt er farlige. Denne myten gir grobunn for stigmatisering og kan bidra til at pasienter og pårørende søker nødvendig helsehjelp for sent. De aller fleste som periodevis eller mer kontinuerlig sliter med psykiske problemer, er fredelige men- nesker. Imidlertid er det et faktum at risikoen for voldsanvendelse rettet mot medmennesker statistisk sett er høyere hos personer med psykiatriske lidelser enn $i$ befolkningen for øvrig $(1,2)$. Derfor vil helsepersonell i barne- og ungdomspsykiatrien, voksenpsykiatrien og alderspsykiatrien kunne regne med enkelte ganger å oppleve farefulle situasjoner. Men slike hendelser kan også finne sted i primærhelsetjenesten og i den øvrige spesialisthelsetjenesten, av og til også der med tragisk utfall.

Generelt sett er dette et tema som er ubehagelig å ta opp og som for det meste unngås i utdanningen av helsepersonell. De fleste møter derfor uforberedt på arbeidsplassen. Heller ikke der gjøres det vanligvis nødvendige forberedelser for å sette de ansatte i stand til å mestre farefulle situasjoner på en hensiktsmessig måte. Helsepersonell læres først og fremst opp til å beskytte pasienten. Noen ganger må imidlertid fokus utvides til å innbefatte en selv, medarbeidere og andre personer, som kan være utenforstående.

\section{Voldsrisiko}

Pasienter med mentale lidelser er som oftest ikke farlige, og de som er potensielt farlige 
er ikke det alltid. Farlighet er gjerne situasjonsbestemt. Det er alltid vanskelig å forutse det som kommer til å skje. Likevel er det en del forhold, såkalte varige risikofaktorer, som kan hjelpe oss til å skjerpe årvåkenheten, men som til dels krever grundig arbeid med anamnesen og den kliniske undersøkelsen for at vi skal få fatt i dem. Det dreier seg oftere om menn enn kvinner. Tidligere episoder med vold og trusler fra pasienten, eventuelt innad i familien, forutsetter oftest pålitelige komparentopplysninger. Likeledes vil supplerende informasjon være nyttig for å kunne bedømme personligheten, der spesielt manglende empati er en risikofaktor. Andre risikofaktorer er rusmisbruk, lav utdanning, en sykehistorie med mange innleggelser på psykiatriske døgninstitusjoner, og dessuten manglende tilhørighet, tilfredsstillende bosituasjon og sosial støtte.

Dynamiske risikofaktorer er mer situasjonsbestemt. Det kan dreie seg om en aktuell livssituasjon preget av ustabil sosial tilhørighet og/eller sykdomsfase med tilstedeværelse av spesielle symptomer. Skjerpet årvåkenhet bør utløses når pasienten opplever psykotiske symptomer som er truende og som vedkommende ikke klarer å kontrollere. Et eksempel på dette er kommanderende stemmer (hørselshallusinose). Det samme gjelder der hvor pasienten mangler innsikt og ikke forstår at symptomene er sykelige og nødvendiggjør behandling. Det fører ofte til at pasienten slutter å ta virksom antipsykotisk medisin, med forverring til følge. Andre psykopatologiske tilstander som bør utløse årvåkenhet hos behandlerne, er knyttet til sterk mistenksomhet hos personer i psykotisk fase, utpreget irritabilitet som kan oppleves hos pasienter med bipolar lidelse særlig i manisk fase, og manglende evne til å ta andres perspektiv, som spesielt er fremtredende hos personer med antisosiale personlighetstrekk. Voldsangrep kan da være planlagt, målrettet og komme plutselig og uventet. I spesielle situasjoner er også tilgang til våpen en risikofaktor (2).

\section{Voldsrisikovurdering}

På bakgrunn av disse erfaringene er det de siste årene forsøkt utarbeidet korte og anvendelige screeninginstrumenter til hjelp for å kunne predikere voldsrisiko. Et godt eksempel er en norsk utgave som lister opp ti risikofaktorer. Disse er henholdsvis tidligere og/eller aktuell vold, tidligere og/eller aktuelle trusler, tidligere og/eller aktuelt rusmisbruk, tidligere og/eller aktuell alvorlig psykisk lidelse, personlighetsforstyrrelse, manglende innsikt, mistenksomhet, manglende empati, urealistiske planer for fremtiden og mangelfull stressmestringsevne (3).

\section{Tiltak}

Helsepersonell som utsettes for alvorlige trusler eller vold, trenger oppmerksomhet (debriefing) så raskt som mulig etter hendelsen, og i hvert fall i løpet av det første døgnet. Det gjelder å få luftet ut i trygge omgivelser, og ethvert behandlingsmiljø bør ha rom for dette. Vi må hjelpe hverandre med å dele erfaringer. I denne sammenhengen bør fokus være å lære av det oppståtte med den hensikt å bli flinkere til å forutse og forhindre liknende hendelser og å være bedre forberedt dersom det skulle skje. Helsepersonell trenger dessuten mulighet for fortløpende og god veiledning. Det gjelder også for overleger.

Alle pasienter må behandles med respekt, ikke minst de som opptrer truende. Da blir det viktig å forsøke å berolige på en empatisk, men likevel fast måte. Dette er selvsagt vanskelig når man selv er redd. Da må man tilkjempe seg all den styrke og ro som kan mobiliseres. Det er faktisk på mange måter som å spille en rolle som skuespiller. Slike oppgaver løses best dersom man er forberedt og har trent. Relevant trening går ut på å lære seg til å gjenkjenne faresituasjoner, unngå uheldige konfrontasjoner og til å håndtere konflikter. Det gjelder å holde øyekontakt og snakke rolig på pasientens kognitive forståelsesnivå. Avledning og/ eller å gi alternative løsningsforslag er ofte nyttig, og krisehåndteringen skjer best i rolige omgivelser uten andre pasienter og bråk rundt. Ingen trussel bør fremsettes, og du må vise at du bryr deg og lytter til pasienten. Autoritær tilsidesetting av pasientens synspunkter og rett til å ytre seg vil bare føre til uheldig eskalering. Hold passe fysisk avstand, ikke for nær pasienten, og engasjer gjerne personer som pasienten har spesiell tillit til. Alt dette krever en stor grad av fleksibilitet og evne til raskt å oppfatte og analysere det som skjer fortløpende.

Det gjelder å være realistisk med hensyn til hva som kan møte oss i arbeidslivet og å være godt forberedt. Både kompliserte kirurgiske inngrep og krisehåndtering i farlige situasjoner der interpersonelle relasjoner settes på prøve, er krevende oppgaver som forutsetter stadig trening for å kunne beherskes.

\section{Stein Opjordsmoen Ilner}

s.e.o.ilner@medisin.uio.no

Klinikk psykisk helse og avhengighet

Oslo universitetssykehus, Ullevål

og

Det medisinske fakultet

Universitetet i Oslo

Stein Opjordsmoen Ilner (f. 1942) er dr.med. og spesialist i nevrologi og spesialist i psykiatri. Han er professor i psykiatri og overlege ved Avdeling for forskning og undervisning, Oslo universitetssykehus.

Litteratur

1. Drap i Norge i perioden 2004-2009. NOU 2010: 3. Oslo: Helse- og omsorgsdepartementet, 2010. www.regjeringen.no/nb/dep/hod/dok/nouer/2010/ NOU-2010-3.html?id=602257 (7.4.2011).

2. Riba MB, Ravindranath D, red. Clinical manual of emergency psychiatry. Washington, D.C. American Psychiatric Publishing, 2010.

3. Roaldset JO, Hartvig P. Bjørkly S. V-RISK-10: Validation of a screen for risk of violence after discharge from acute psychiatry. Eur Psychiatry 2011 $26: 85-91$.

Mottatt 7.4. 2011 og godkjent 10.4. 2011. Medisinsk redaktør Erlend Hem. 